\title{
Międzynarodowa konferencja naukowa „Zagadnienia aktualne historii państwa i prawa krajów Centralno-Wschodniej Europy" - Lwów 24-25 kwietnia 2009 r.
}

W dniach 24-25 kwietnia 2009 r. odbyła się we Lwowie Międzynarodowa konferencja naukowa na temat:„Актуальни проблеми исторії держави і права країн Центрально-Східної Европи" (Zagadnienia aktualne historii państwa i prawa krajów Centralno-Wschodniej Europy). Konferencja zorganizowana została wspólnie przez Katedrę Historii Państwa, Prawa i Nauk Polityczno-Prawnych i Katedrę Zasad Prawa Ukrainy, Wydziału Prawa Lwowskiego Narodowego Uniwersytetu im. Iwana Franki. Okolicznością skłaniającą do podjęcia tej inicjatywy była upływająca w 2008 r. 150. rocznica urodzin wybitnego historyka ustroju i prawa polskiego profesora Oswalda Balzera (1858-1933).

W imieniu organizatorów uroczystego otwarcia obrad dokonał A. Bojko, dziekan Wydziału Prawa Lwowskiego Narodowego Uniwersytetu im. Iwana Franki. Konferencja zgromadziła przedstawicieli wielu ośrodków naukowych. Ukrainę, poza gospodarzami z Lwowskiego Narodowego Uniwersytetu im. Iwana Franki, reprezentowali badacze z Mariupolskiego Państwowego Uniwersytetu Humanistycznego, Odeskiej Narodowej Akademii Prawniczej i Tarnopolskiego Narodowego Uniwersytetu Ekonomicznego. Do Lwowa przybyli również naukowcy z Austrii (Uniwersytet Wiedeński), Czech (Zachodnioczeski Uniwersytet w Pilźnie), Niemiec (Wolny Uniwersytet w Berlinie) i Polski (Katolicki Uniwersytet Lubelski Jana Pawła II, Uniwersytet Jagielloński w Krakowie, Uniwersytet Marii Curie-Skłodowskiej w Lublinie, Uniwersytet Wrocławski, Uniwersytet Zielonogórski i Uniwersytet w Białymstoku). W programie konferencji znalazło się 45 referatów, wygłaszanych w trzech językach: ukraińskim, polskim i niemieckim. Tematy wystąpień dotyczyły m.in.: B. Tyszczyk (Lwowski Narodowy Uniwersytet im. Iwana Franki), Освальд Марян Балиер як науковець, керівник кафедри i neдагог; P. Jurek (Uniwersytet Wrocławski), Cezura czasowa oddzielajaca Polskę Ludowa od III Rzeczypospolitej; T. Andrusiak (Lwowski Narodowy Uniwersytet im. Iwana Franki), Освальд Балиер і Наукове Товариство ім. Шевченка; $\mathrm{U}$. Eisenberg (Wolny Uniwersytet w Berlinie), Aktuelle Streitstände im deutschen Jugendstrafrecht; I. Lewandowska-Malec (Uniwersytet Jagielloński w Krakowie), Potrzeba nowej periodyzacji dziejów i nowych badań nad historiq ustroju państwa; J. Koredczuk (Uniwersytet Wrocławski), Badania nad historia ustroju i prawa Rosji w nauce polskiej po 1989 r.; A. Wrzyszcz, W. P. Tekely (Uniwersytet Marii Curie-Skłodowskiej w Lublinie), Nauczanie historii prawa polskiego dawniej i dziś - od ujęcia Oswalda Balzera po czasy wspótczesne; V. Knoll (Zachodnioczeski Uniwersytet w Pilźnie), Juden im Licht der Achtbücher im mittelalterlichen Eger. Ein Hinweis zu ihrer Stellung in der Stadt; M. Dyjakowska (Katolicki Uniwersytet Lubelski Jana Pawła II), Naruszenie bezpieczeństwa sędziów i obrad sądów 
ze szczególnym uwzględnieniem Trybunału Koronnego jako crimen laesae maiestatis; M. Bajmuratow (Mariupolski Państwowy Uniwersytet Humanistyczny), Роль Магдебурзького права в розвитку міст на украӥнських землях в період периої Речі Посполитої; A. Bereza, A. Fermus-Bobowiec (Uniwersytet Marii Curie-Skłodowskiej w Lublinie), Najwyższy sąd szlachty w pracach Oswalda Balzera $i$ w badaniach współczesnych; E. Szczot (Katolicki Uniwersytet Lubelski Jana Pawła II), Ewolucja pojęcia „rodzina”; L. Fiejdasz (Katolicki Uniwersytet Lubelski Jana Pawła II), Ruch „księży patriotów” w krajach Europy Środkowo-Wschodniej; R. Małachowski (Uniwersytet Zielonogórski), Aspekty prawne i ustrojowo-polityczne edukacji katolickiej $w$ Polsce $w$ latach 1945-2008, N. Jefremowa (Odeska Narodowa Akademia Prawnicza), Розробка та прийняття перших конституцій в Австрійській імперії 1848-1849 рp.; M. Mikuła (Uniwersytet Jagielloński w Krakowie), Edycja nowożytnych miejskich ksiag sądowych karnych. Stan obecny i postulaty wydawnicze; K. Szczygielski (Uniwersytet w Białymstoku), $Z$ badań nad prawem rzymskim na Uniwersytecie Stefana Batorego $w$ Wilnie.

Prezentowane wystąpienia spotkały się z dużym zainteresowaniem uczestników obrad, czego dowodem była żywa dyskusja. Konferencji towarzyszyła także wystawa prac naukowych Oswalda Balzera. Wszyscy obecni we Lwowie zgodnie podkreślali ogromną życzliwość i serdeczność, z jaką zostali przyjęci. Organizatorzy zapewnili, iż wygłoszone referaty zostaną wkrótce ogłoszone drukiem.

Krzysztof Szczygielski 